\title{
Study on the Relation between Tailing Particle Size and Tailing Slurry Underflow Concentration
}

\author{
Yi Zou $\mathbb{D}^{1},{ }^{1}$ Qi Liu $\left(\mathbb{D},{ }^{2,3}\right.$ and Weijun Liu $\mathbb{D}^{2}$ \\ ${ }^{1}$ Zijin Mining Group Co. Ltd., Xiamen 364200, China \\ ${ }^{2}$ Changsha Mining Research Institute Co., Ltd., Changsha 410012, China \\ ${ }^{3}$ DAYE NONFERROUS METALS GROUP HOLDINGS Co., Ltd., Huangshi 435111, China \\ Correspondence should be addressed to Qi Liu; 345926583@qq.com
}

Received 5 November 2021; Accepted 18 December 2021; Published 17 January 2022

Academic Editor: Erol Yilmaz

Copyright ( $\odot 2022$ Yi Zou et al. This is an open access article distributed under the Creative Commons Attribution License, which permits unrestricted use, distribution, and reproduction in any medium, provided the original work is properly cited.

\begin{abstract}
In order to study the effect of the physical properties of tailings on the concentration of tailing slurry underflow, the median particle size, control particle size, and density of the tailings of 9 typical mines were measured. Besides, static settlement test and dynamic thickening test of the tailing slurry of these 9 mines were separately conducted. The test results show that the underflow concentration of the tailing slurry is unrelated to the tailing density but is related to the tailing particle size. The finer the tailing particle size, the lower the underflow concentration. Through the nondimensional regression analysis, 3 relation equations were obtained: number 1 relation equation between the median particle size of tailings and the underflow concentration in the static settlement test, number 2 relation equation between the control particle size of tailings and the change in concentration in the static settlement test, number 3 relation equation between the underflow concentration in the static settlement test and the underflow concentration in the dynamic thickening test under different overflow water solid content conditions. Comparing the calculation results with the test results, it is found that the relative error between the predicted value and the test value does not exceed $6.1 \%$, which has proved that the relation equations derived are convenient and feasible. The underflow concentration of the deep cone thickener can be predicted by merely measuring the particle size of the tailings, which means that the relation equations are highly recommended for wider use and application.
\end{abstract}

\section{Introduction}

With the progress and development of filling technology, more and more mines (especially metal mines) adopt or switch to the filling mining method [1-3]. The key technology of the filling mining method is the preparation of filling slurry (mainly composed of filling aggregate, cementitious material, and water) [4-6]. Due to a wide range of sources and low cost, tailings are often used as the main filling aggregate $[7,8]$. Tailings are derived from the tailing slurry discharged after the mineral processing, and its concentration is normally only $10 \% \sim 25 \%$, which means it cannot be directly used to prepare high-concentration filling slurry. However, as for full tailing filling, especially cemented filling, it is required that the concentration of filling slurry should reach normally $65 \%$ to
$75 \%$ and even higher for paste filling $[9,10]$. Therefore, the tailing slurry must be concentrated and dehydrated before being used as a filling aggregate. The high-rate thickening of the tailing slurry is the key part of the full tailing filling technology $[11,12]$. The underflow concentration is a key technical parameter for the thickening performance of tailings $[13,14]$. It is found that the final underflow concentration greatly varies in the flocculation settlement tests of tailings from different mines.

At present, there are a lot of research studies on the sedimentation law and dense performance (underflow concentration, settlement speed, etc.) of the tailing slurry in both static settlement test and dynamic thickening test. In terms of static settlement test, Zhu [15] studied the relation between tailing particle size and underflow concentration and found that the higher the content of 
fine particles in the tailings, the lower the underflow concentration; Grangeia et al. and [16] Arjmand [17] et al. have found that rapid tailing sedimentation can be achieved by selecting appropriate flocculant with proper dosage and the optimal tailing slurry concentration. Chen [18] used the Altman method to study the relation between settling time and the sedimentation height of the tailing slurry under different particle size conditions; Dong [19] sampled tailings from an iron mine, then studied the relation between the unit consumption of flocculant and the settling speed of this mine's tailing slurry under different tailing slurry concentrations, and then studied the relation between the unit consumption of flocculant and the ultimate underflow concentration under different tailing slurry concentrations; Wang et al. [20] found that the tailing slurry can be magnetized to improve the sedimentation performance; Liyi et al. [21] found that sound waves can improve the sedimentation performance of tailings. In terms of dynamic thickening, Gao et al. [22] found that the underflow concentration will increase with the increase in the mud layer height in the thickener, but when the mud layer height increases to a certain height, the underflow concentration will no longer increase; Gao et al. [23] found that the underflow concentration is inversely proportional to solid flux, that is, the greater the tailing slurry processing capacity per unit area of the thickener, the lower the corresponding underflow concentration; $\mathrm{Li}$ et al. [24] found that the continuous disturbance of the tailing slurry by the thickener rake arm can significantly increase the settlement speed and the underflow concentration. That is, when using the same tailing slurry, the settlement speed of the dynamic thickening test is $20 \%$ faster than that of the static settlement test, and the underflow concentration is $8 \% \sim 15 \%$ higher; Gongcheng [25] studied the influence of the size change in the tailing flocculation on the denseness performance of the tailing slurry with different speed of the thickener rake arm.

The focus of the above studies is to use a certain agent and/or technical methods to improve the settlement performance parameters of tailing slurry but did not go to an indepth study of what causes the differences in thickening performance between different tailings. So far, there is no report on the quantitative relation between the underflow concentration of tailing slurry and the particle size of tailings. Therefore, the settlement test of the tailing slurry of 9 metal mines was carried out to study the relation among the composition of the tailing particle size, the optimal diluted concentration, and underflow concentration in both static settlement test and dynamic thickening test. Taking into account the length of the study, only the static settlement test and dynamic thickening test processes and results of Mine 2 are listed in this study. For the rest of the mines, only the test results are listed and the test process is not written. Considering that the sedimentation law and complicated denseness of the tailing slurry, especially the combined test of static and dynamic settlement, which has many influence factors, it is necessary to study the quantitative relationship equation between the underflow concentration of the slurry and the particle size of the tailings.

\section{Process and Results of Static Settlement Test}

2.1. Particle Size and Density of Tailings. A Malvern particle size analyzer was used to measure the tailing particle size (including control particle size and median particle size) of 9 mines, and a $25 \mathrm{~mL}$ pycnometer was used to measure the true density of the tailings of these 9 mines. The test results are shown in Table 1. It can be seen from Table 1 that the particle sizes of tailings from Mine 1 (bauxite mine in Guangxi province), Mine 2 (gold mine in Hunan province), and Mine 3 (iron mine in Shandong province) are relatively fine, the particle sizes of tailings from Mine 4 (iron mine in Hubei province), Mine 5 (polymetallic mine in Tibet), and Mine 6 (gold mine in Xinjiang province) are moderate, and the particle sizes of tailings from Mine 7 (copper mine in Yunnan province), Mine 8 (gold mine in Jiangxi province), and Mine 9 (lead and iron mines in Yunnan province) are relatively coarse.

2.2. Process of Static Settlement Test. Mine 2 is taken as an example. Under the same slurry concentration, three anionic flocculants are added, 83376, AG9020, and $665 \mathrm{~V}$, at a ratio of $20 \mathrm{~g} / \mathrm{t}$, respectively. The 83376 flocculant is finally recommended to be used for Mine 2 tailings, after comparing the factors including sedimentation speed, clear liquid clarification degree, and underflow concentration.

\subsubsection{Experiment on the Optimal Flocculant Addition Ratio.} After determining the optimal flocculant, a control test was carried out in order to obtain the optimal tailing slurry concentration under different dosages of the flocculant. The tailing slurry was selected with different concentrations, and a control test was arranged: 83376 flocculant was separately added into four types of tailings (with tailings density of $20 \%, 16 \%, 13 \%$, and $11 \%$ ), in three times for each type. The first addition of flocculant was with the proportion of $15 \mathrm{~g} / \mathrm{t}$, $20 \mathrm{~g} / \mathrm{t}$ the second, and $25 \mathrm{~g} / \mathrm{t}$ the third, and the optimal test results under static settlement test were obtained. The static settlement test results of Mine 2 are shown in Figure 1.

It can be seen in Figure 1 that within a certain range $(15 \mathrm{~g} / \mathrm{t} \sim 25 \mathrm{~g} / \mathrm{t})$, the speed of tailing settlement gradually increased as more flocculant was added into the tailing slurry, and it slowed down after the amount of flocculant reached $20 \mathrm{~g} / \mathrm{t}$. Therefore, the optimal addition ratio of 83376 type flocculant is $20 \mathrm{~g} / \mathrm{t}$.

2.2.2. Optimal Diluted Concentration. The optimal mass concentration of Mine 2 can be determined through the relation between solid flux and filling tailing slurry concentration. The relation curve is shown in Figure 2. It can be seen from Figure 2 that when the tailing slurry concentration is $14 \%$, the solid flux is the largest, which means the optimal value of the tailing slurry mass concentration is about $14.0 \%$.

The final tailing flocculant addition scheme of Mine 2 is as follows: flocculant model 83376, flocculant addition amount $20 \mathrm{~g} / \mathrm{t}$, and tailing slurry diluted concentration $14.0 \%$. 
TABLE 1: Summary of static flocculation settlement test results of various mines.

\begin{tabular}{|c|c|c|c|c|c|c|c|c|}
\hline \multirow[b]{2}{*}{$\begin{array}{l}\text { Sample } \\
\text { no. }\end{array}$} & \multirow{2}{*}{$\begin{array}{c}\text { Density } \\
\gamma /\left(\mathrm{g} \cdot \mathrm{cm}^{-3}\right)\end{array}$} & \multicolumn{2}{|c|}{ Particle size $(\mathrm{mm})$} & \multirow{2}{*}{$\begin{array}{c}\text { Optimal diluted } \\
\text { concentration } \\
C_{0} \\
(\%)\end{array}$} & \multirow[b]{2}{*}{$\begin{array}{c}\text { Underflow } \\
\text { concentration } \\
C_{1}(\%)\end{array}$} & \multirow[b]{2}{*}{$\begin{array}{c}\text { Optimal } \\
\text { flocculant type }\end{array}$} & \multirow[b]{2}{*}{$\begin{array}{l}\text { Unit consumption } \\
\text { of } \\
\text { flocculant } /\left(\mathrm{g} \cdot \mathrm{t}^{-1}\right)\end{array}$} & \multirow[b]{2}{*}{ Remark } \\
\hline & & $\begin{array}{l}\text { Median } \\
\text { particle } \\
\text { size } d_{50}\end{array}$ & $\begin{array}{c}\text { Control; } \\
\text { particle size } \\
d_{60}\end{array}$ & & & & & \\
\hline Mine 1 & 2.010 & 0.0282 & 0.0391 & 17.5 & 53.1 & AG9020 & 20.000 & Bauxite \\
\hline Mine 2 & 2.611 & 0.0335 & 0.0423 & 14.0 & 53.5 & 83376 & 20.000 & Iron mine \\
\hline Mine 3 & 2.322 & 0.0217 & 0.0302 & 10.1 & 42.7 & 83376 & 30.000 & Gold mine \\
\hline Mine 4 & 2.871 & 0.0492 & 0.0625 & 16.5 & 59.5 & 83376 & 10.000 & $\begin{array}{l}\text { Polymetallic } \\
\text { mine }\end{array}$ \\
\hline Mine 5 & 2.880 & 0.0443 & 0.0540 & 13.2 & 55.3 & $6013 S$ & 15.000 & Iron mine \\
\hline Mine 6 & 2.560 & 0.0548 & 0.0723 & 14.0 & 59.3 & AG9020 & 10.000 & Gold mine \\
\hline Mine 7 & 2.689 & 0.1088 & 0.1407 & 16.7 & 68.0 & 76 & 10.000 & Iron mine \\
\hline Mine 8 & 2.451 & 0.1012 & 0.1288 & 14.0 & 64.7 & AG6025 & 10.000 & $\begin{array}{l}\text { Lead iron } \\
\text { mine }\end{array}$ \\
\hline Mine 9 & 3.009 & 0.0847 & 0.1055 & 16.7 & 63.8 & 83376 & 7.500 & Copper mine \\
\hline
\end{tabular}

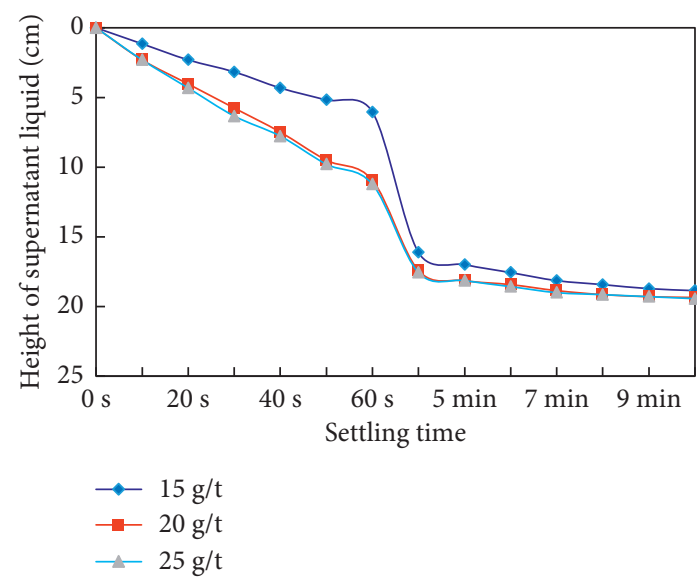

(a)

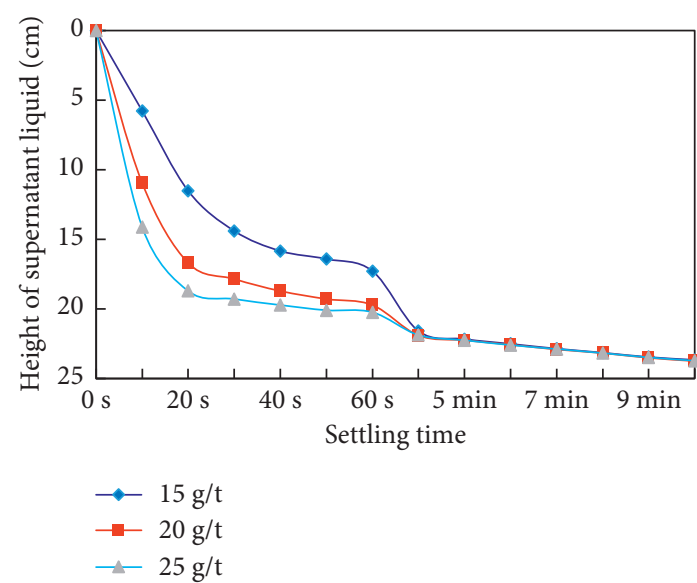

(c)

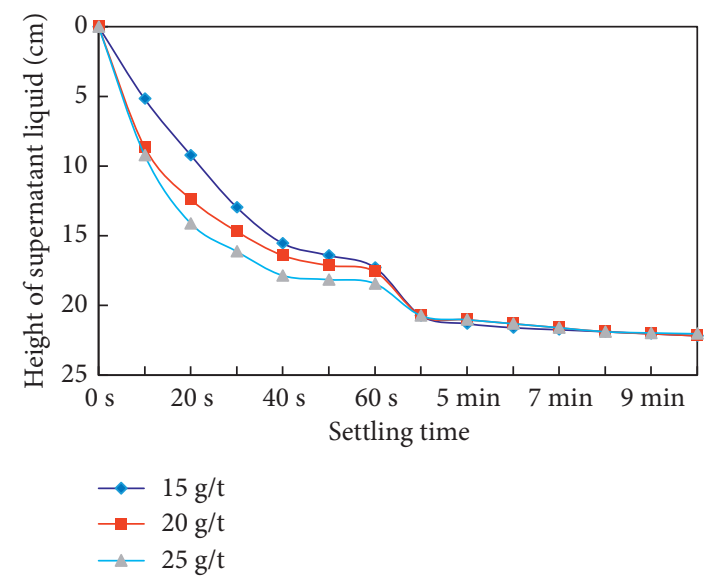

(b)

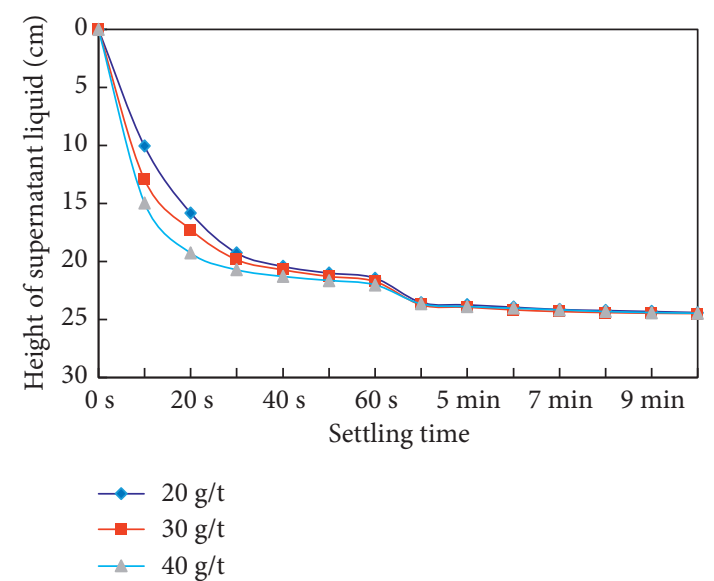

(d)

FIGURE 1: Settlement curves of different tailing slurry concentrations, (a) tailing slurry concentration at 20\%, (b) tailing slurry concentration at $16 \%$, (c) tailing slurry concentration at $13 \%$, and (d) tailing slurry concentration at $11 \%$.

2.3. Results of Static Settlement Test. The relation among the particle size and density of the tailings, the optimal flocculant type, the optimal flocculant addition, the optimal tailing slurry diluted concentration, and the tailing slurry throughput per unit area of 9 mines are shown in Table 1. 


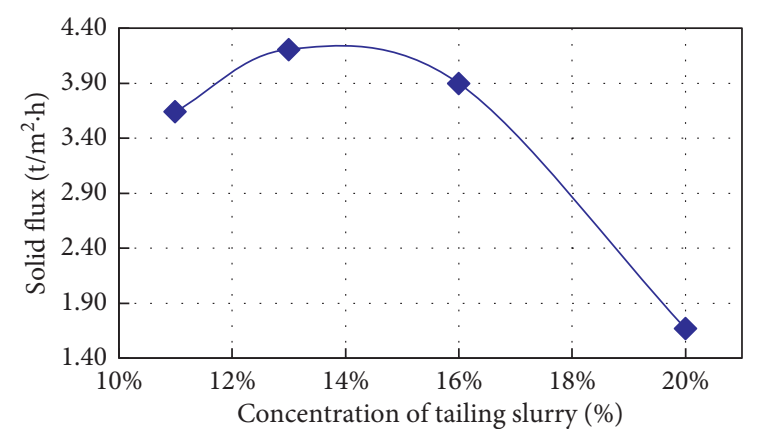

Figure 2: Settlement curves with different tailing slurry concentrations.

\section{Relation between Tailing Particle Size and Underflow Concentration in Static Settlement Test}

It can be seen in Table 1 that the coarser the tailing particle size is, the greater the underflow concentration becomes. In addition, there is a high degree of nonlinear correlation between both the median particle size of tailings and the control particle size of tailings with the underflow concentration. The function relation between both the median particle size and the control particle size of the tailings and the concentration of the tailing underflow is shown in equations (1) and (2). Considering the physical meaning of the fitting formula, when there are no tailings in the slurry, that is, when the particle size is close to 0 , the underflow concentration $\mathrm{C} 1$ should also be 0 . According to formula (1), when $\mathrm{d} 50$ is 0 , the underflow concentration is -2.77 . According to formula (2), when d60 is 0 , the underflow concentration is $-14.4 \%$. It can be seen that the underflow concentration value calculated by the median particle size $\mathrm{d} 50$ is closer to the actual situation and more reliable.

$$
\begin{aligned}
C_{1}= & -20848 d_{50}{ }^{4}+6387.5 d_{50}{ }^{3}-701.6 d_{50}{ }^{2} \\
& +34.009 d_{50}-0.0277 . \\
C_{1}= & -8614.9 d_{60}{ }^{4}+3445.7 d_{60}{ }^{3}-495.94 d_{60}{ }^{2} \\
& +31.373 d_{60}-0.144 .
\end{aligned}
$$

In the formula, $\mathrm{C}_{0}$ is the initial slurry concentration, that is, the optimal slurry diluted concentration (\%) in Table $1 ; \mathrm{C}_{1}$ is the underflow concentration. Figure 3

Through the settlement test, it is found that the greater the initial slurry concentration is, the higher the underflow concentration becomes. Therefore, it is necessary to consider the relation between the change in slurry concentration (the difference between the underflow concentration and the initial concentration) and the particle size of the tailings. The relation between the change in slurry concentration and the particle size of tailings is shown in Figure 4. It can be seen from the figure that there is not only a certain functional relation between the median particle size and the change in slurry concentration but also a certain functional relation between the control particle size of the tailings and the change in slurry concentration, and both R-squared are close to 99\%. From the perspective of the degree of fit, as long as the median particle size or control particle size of the tailings is known, the change in slurry concentration can be predicted. The functional relation is shown in equations (3) and (4).

$$
\begin{aligned}
C_{1}-C_{0}= & -3993 d_{50}^{4}+1671.6 d_{50}{ }^{3}-237.43 d_{50}{ }^{2} \\
& +15.087 d_{50}+0.0917 \\
C_{1}-C_{0}= & -4082.8 d_{60}{ }^{4}+1708.2 d_{60}{ }^{3}-259.52 d_{60}{ }^{2} \\
& +17.909 d_{60}-0.0252 .
\end{aligned}
$$

Considering the physical meaning of the fitting formula, when there are no tailings in the slurry, that is, when the particle size is close to 0 , the change in underflow concentration $\mathrm{C}_{1}-\mathrm{C}_{0}$ should also be 0 . According to formula (3), when $d_{50}$ is 0 , the change in underflow concentration is $9.17 \%$, and when $d_{60}$ is 0 , the change in underflow concentration is $-2.52 \%$, which shows that using the control particle size $d_{60}$, the calculated underflow concentration is more reliable.

\section{Process and Results of Dynamic Thickening Test}

4.1. Dynamic Thickening Test Equipment and Method. The dynamic thickening test uses 4 peristaltic pumps, which are used to pump dilution water, to pump flocculant, to pump tailing samples into the feeding system of the thickening test device, and to pump the underflow from the bottom of the test device. The dilution water is tap water; the flocculant is added through two different dosing points, and the addition amount is based on the data obtained from the static settlement test; the mass concentration of the tailing slurry is about $10 \%$ to $18 \%$, and then, it is placed in a $100 \mathrm{~L}$ barrel with an electric mixer. All materials are fully mixed and finally pumped into the pipeline. The speed of the peristaltic pump is adjusted by calculation to make the flocculant and tailing sample reach the optimal addition ratio of the static settlement test and to simulate the results of the thickener under different conditions. When the height of the mud layer is $150 \mathrm{~mm}$, then the measurement of the overflow water begins, and when the height of the mud layer is $240 \mathrm{~mm}$, then the measurement of the underflow begins. The equipment required for the dynamic thickening test is shown in Figure 5.

4.2. Dynamic Thickening Test. According to the optimal flocculant type, flocculant unit consumption, and slurry diluted concentration obtained in the static settlement test, the effects of different feeding speeds (the rate of addition of tailing slurry) on overflow water clarity and underflow concentration in 9 mines were studied, respectively. The test results are shown in Table 2, while the underflow tailing samples are shown in Figure 6. 


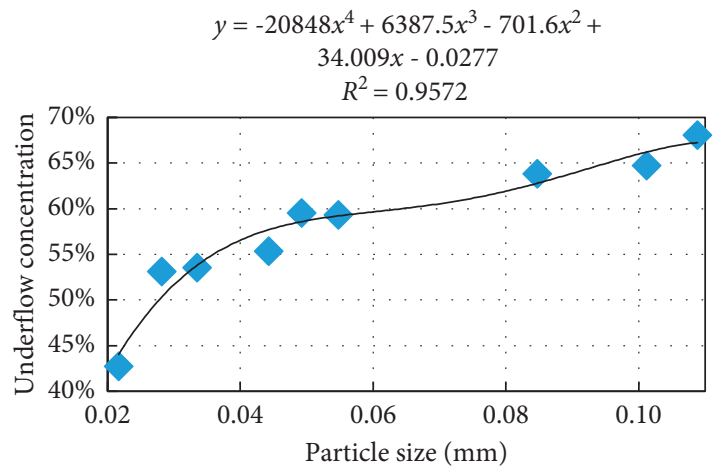

(a)

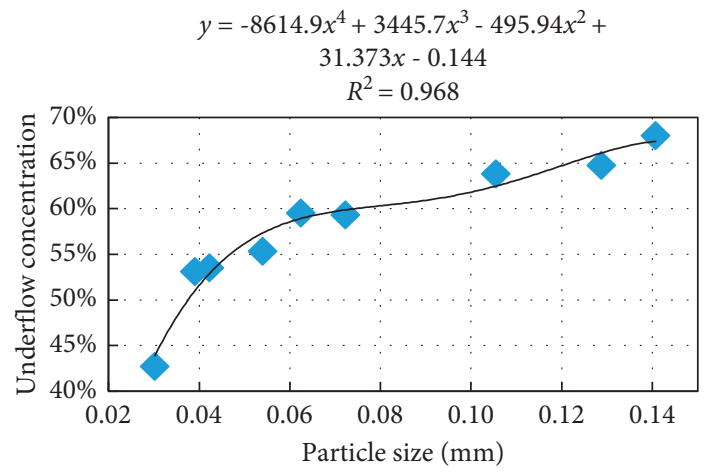

(b)

Figure 3: Nonlinear relation between particle size of tailings and underflow concentration. (a) Median particle size of tailings. (b) Control particle size of tailings.

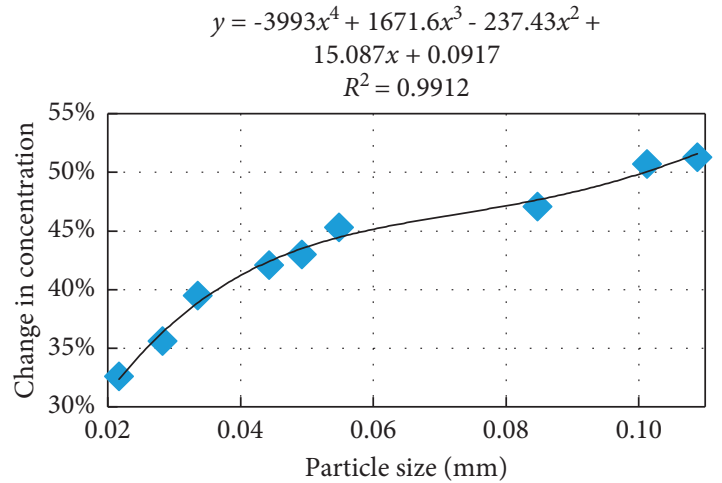

(a)

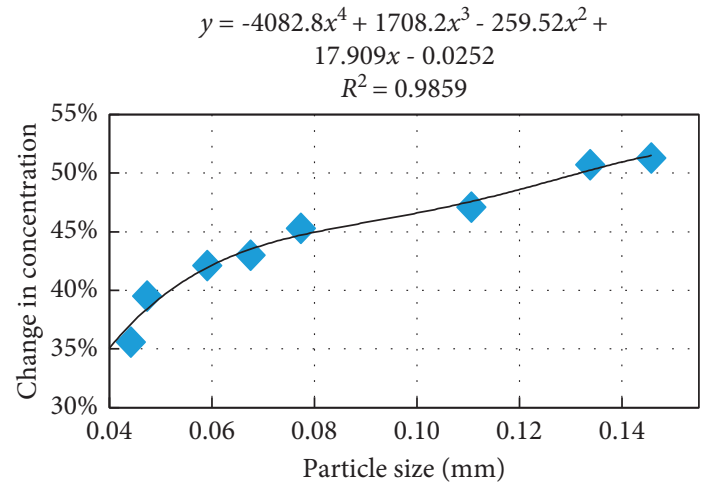

(b)

Figure 4: Nonlinear relation between particle size of tailings and change in concentration. (a) Median particle size of tailings. (b) Control particle size of tailings.

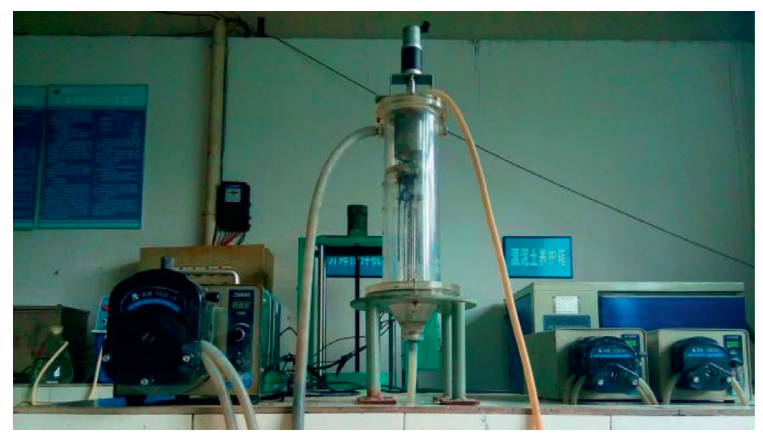

Figure 5: Dynamic thickening test equipment.

\section{The Relation between Tailing Particle Size and Tailing Slurry Underflow Concentration}

By analyzing the dynamic thickening test results, it is found that as the feeding speed decreases, the solid content of the overflow water gradually decreases, and the underflow concentration gradually increases. The main reason for this phenomenon is that the slower feeding speed prolonged the flocculation reaction time of tailing particles and the flocculation reaction is more thorough so that the solid content of the overflow water gradually decreases and the underflow concentration gradually increases. In the dynamic thickening test, the solid content of the overflow water at different feeding speeds is $50-400 \mathrm{ppm}$.

5.1. The Relation between Slurry Feeding Speed and Overflow Solid Content. The slurry feeding speed is an important index that affects the design of the tailing conveying system of the mineral processing plant and the thickening capacity of the deep cone thickener. The feeding speed is mainly determined through the thickening effect, especially the solid content of the overflow water. Using Mine 2 as an example, the relation between the feeding speed and the solid content of the overflow water in this mine is shown in Figure 7(a). In Figure 7(a), it is not only the fitting curve of the feeding speed and the solid content of the overflow water that are given but also the 3 rddegree polynomial function with its R-squared is given. The relation between the feeding speed and the solid content of the overflow water of these 9 mines is shown in Table 3. 
TABLE 2: Results of dynamic thickening test.

\begin{tabular}{|c|c|c|c|c|c|c|c|c|c|c|}
\hline \multirow{2}{*}{$\begin{array}{l}\text { Sample } \\
\text { no. }\end{array}$} & \multirow{2}{*}{$\begin{array}{l}\text { Test } \\
\text { no. }\end{array}$} & \multirow{2}{*}{$\begin{array}{c}\text { Slurry } \\
\text { feeding } \\
\text { speed } \\
v /(\mathrm{L} / \mathrm{min})\end{array}$} & \multirow{2}{*}{$\begin{array}{c}\text { Slurry } \\
\text { concentration } \\
C_{0}(\%)\end{array}$} & \multicolumn{2}{|c|}{ Slurry weight (kg ) } & \multirow{2}{*}{$\begin{array}{l}\text { Tailing } \\
\text { density }\end{array}$} & \multirow{2}{*}{$\begin{array}{c}\text { Tailings } \\
\text { consumption } \\
(\mathrm{kg})\end{array}$} & \multirow{2}{*}{$\begin{array}{l}\text { Time } \\
(\mathrm{min})\end{array}$} & \multirow{2}{*}{$\begin{array}{l}\text { Underflow } \\
\text { concentration }\end{array}$} & \multirow{2}{*}{$\begin{array}{c}\text { Overflow } \\
\text { solid content } \\
\text { f/ppm }\end{array}$} \\
\hline & & & & $\begin{array}{c}\text { Before } \\
\text { test }\end{array}$ & $\gamma /\left(\mathrm{g} \cdot \mathrm{cm}^{-3}\right)$ & & & & & \\
\hline \multirow{7}{*}{ Mine 1} & 1 & 0.12 & 17.5 & 60 & 56.19 & 2.01 & 0.666 & 30 & 67.95 & 48.35 \\
\hline & 2 & 0.15 & 17.5 & 56.19 & 51.33 & 2.01 & 0.851 & 30 & 67.86 & 78.22 \\
\hline & 3 & 0.17 & 17.5 & 51.33 & 45.67 & 2.01 & 0.992 & 30 & 67.8 & 96.21 \\
\hline & 4 & 0.21 & 17.5 & 45.67 & 38.63 & 2.01 & 1.233 & 30 & 67.13 & 126.29 \\
\hline & 5 & 0.25 & 17.5 & 38.63 & 30.53 & 2.01 & 1.416 & 30 & 66.86 & 156.21 \\
\hline & 6 & 0.27 & 17.5 & 30.53 & 21.63 & 2.01 & 1.558 & 30 & 66.57 & 267.33 \\
\hline & 7 & 0.30 & 17.5 & 21.63 & 11.86 & 2.01 & 1.709 & 30 & 66.38 & 352.69 \\
\hline \multirow{5}{*}{ Mine 2} & 1 & 0.32 & 14 & 144.7 & 134.05 & 2.611 & 1.491 & 30 & 67.86 & 58.22 \\
\hline & 2 & 0.38 & 14 & 134.05 & 121.44 & 2.611 & 1.765 & 30 & 67.8 & 94.21 \\
\hline & 3 & 0.46 & 14 & 121.44 & 106.31 & 2.611 & 2.119 & 30 & 67.13 & 126.29 \\
\hline & 4 & 0.58 & 14 & 106.31 & 87.25 & 2.611 & 2.668 & 30 & 66.86 & 236.21 \\
\hline & 5 & 0.73 & 14 & 87.25 & 63.42 & 2.611 & 3.336 & 30 & 64.38 & 372.69 \\
\hline \multirow{5}{*}{ Mine 3} & 1 & 0.82 & 10.1 & 130 & 103.86 & 2.322 & 2.64 & 30 & 52.25 & 321.73 \\
\hline & 2 & 0.70 & 10.1 & 103.86 & 81.67 & 2.322 & 2.242 & 30 & 52.78 & 195.17 \\
\hline & 3 & 0.55 & 10.1 & 81.67 & 64.2 & 2.322 & 1.765 & 30 & 53.27 & 115.23 \\
\hline & 4 & 0.46 & 10.1 & 64.2 & 49.64 & 2.322 & 1.47 & 30 & 54.14 & 97.21 \\
\hline & 5 & 0.33 & 10.1 & 49.64 & 39.08 & 2.322 & 1.067 & 30 & 54.53 & 90.45 \\
\hline \multirow{4}{*}{ Mine 4} & 1 & 0.42 & 16.5 & 100 & 85.82 & 2.871 & 2.34 & 30 & 72.95 & 73.58 \\
\hline & 2 & 0.51 & 16.5 & 85.82 & 68.69 & 2.871 & 2.826 & 30 & 72.66 & 96.22 \\
\hline & 3 & 0.61 & 16.5 & 68.69 & 48.35 & 2.871 & 3.357 & 30 & 72.23 & 196.21 \\
\hline & 4 & 0.67 & 16.5 & 48.35 & 25.87 & 2.871 & 3.708 & 30 & 71.43 & 326.29 \\
\hline \multirow{5}{*}{ Mine 5} & 1 & 0.51 & 13.2 & 145 & 128.21 & 2.88 & 2.217 & 30 & 72.63 & 62.68 \\
\hline & 2 & 0.60 & 13.2 & 128.21 & 108.64 & 2.88 & 2.583 & 30 & 71.94 & 101.3 \\
\hline & 3 & 0.72 & 13.2 & 108.64 & 84.86 & 2.88 & 3.138 & 30 & 69.34 & 187.44 \\
\hline & 4 & 0.76 & 13.2 & 84.86 & 59.96 & 2.88 & 3.287 & 30 & 67.75 & 215.87 \\
\hline & 5 & 0.88 & 13.2 & 59.96 & 31.21 & 2.88 & 3.795 & 30 & 66.93 & 312.33 \\
\hline \multirow{5}{*}{ Mine 6} & 1 & 0.44 & 14 & 148 & 133.42 & 2.56 & 2.041 & 30 & 72.52 & 65.43 \\
\hline & 2 & 0.56 & 14 & 133.42 & 115.2 & 2.56 & 2.551 & 30 & 72.24 & 123.47 \\
\hline & 3 & 0.63 & 14 & 115.2 & 94.45 & 2.56 & 2.905 & 30 & 71.85 & 193.89 \\
\hline & 4 & 0.68 & 14 & 94.45 & 72.3 & 2.56 & 3.101 & 30 & 71.33 & 247.22 \\
\hline & 5 & 0.73 & 14 & 72.3 & 48.48 & 2.56 & 3.335 & 30 & 70.82 & 342.1 \\
\hline \multirow{6}{*}{ Mine 7} & 1 & 0.22 & 16.7 & 150 & 142.48 & 2.689 & 1.256 & 30 & 81.65 & 65.45 \\
\hline & 2 & 0.28 & 16.7 & 142.48 & 133.14 & 2.689 & 1.56 & 30 & 81.14 & 78.22 \\
\hline & 3 & 0.46 & 16.7 & 133.14 & 117.61 & 2.689 & 2.592 & 30 & 80.8 & 126.21 \\
\hline & 4 & 0.59 & 16.7 & 117.61 & 97.97 & 2.689 & 3.281 & 30 & 79.4 & 156.29 \\
\hline & 5 & 0.70 & 16.7 & 97.97 & 74.55 & 2.689 & 3.911 & 30 & 78.57 & 291.36 \\
\hline & 6 & 0.81 & 16.7 & 74.55 & 47.5 & 2.689 & 4.517 & 30 & 77.46 & 461.53 \\
\hline \multirow{5}{*}{ Mine 8} & 1 & 0.44 & 14 & 158.1 & 143.86 & 2.451 & 1.994 & 30 & 78.12 & 72.13 \\
\hline & 2 & 0.58 & 14 & 143.86 & 124.97 & 2.451 & 2.643 & 30 & 77.86 & 123.28 \\
\hline & 3 & 0.67 & 14 & 124.97 & 102.98 & 2.451 & 3.079 & 30 & 77.35 & 190.47 \\
\hline & 4 & 0.82 & 14 & 102.98 & 76.08 & 2.451 & 3.766 & 30 & 76.78 & 283.45 \\
\hline & 5 & 0.97 & 14 & 76.08 & 44.26 & 2.451 & 4.455 & 30 & 76.36 & 367.81 \\
\hline \multirow{5}{*}{ Mine 9} & 1 & 0.78 & 16.7 & 130 & 103.6 & 3.009 & 4.409 & 30 & 73.37 & 324.17 \\
\hline & 2 & 0.66 & 16.7 & 103.6 & 81.25 & 3.009 & 3.732 & 30 & 77.05 & 195.23 \\
\hline & 3 & 0.56 & 16.7 & 81.25 & 62.46 & 3.009 & 3.138 & 30 & 78.62 & 107.21 \\
\hline & 4 & 0.49 & 16.7 & 62.46 & 45.8 & 3.009 & 2.782 & 30 & 78.73 & 90.45 \\
\hline & 5 & 0.45 & 16.7 & 45.8 & 30.58 & 3.009 & 2.542 & 30 & 78.78 & 87.62 \\
\hline
\end{tabular}

5.2. The Relation between Slurry Feeding Speed and Underflow Concentration of Dynamic Thickening Test. The slurry feeding speed is closely related to the underflow concentration of the deep cone thickener. The relation between the feeding speed and the underflow concentration of Mine 2 is shown in Figure 7(b). In
Figure 7(b), it is not only the fitting curve of the feeding speed and the underflow concentration that are given but also the 3rd-degree polynomial function with its $\mathrm{R}$-squared is given. The relation between feeding speed and underflow concentration of these 9 mines is shown in Table 4. 

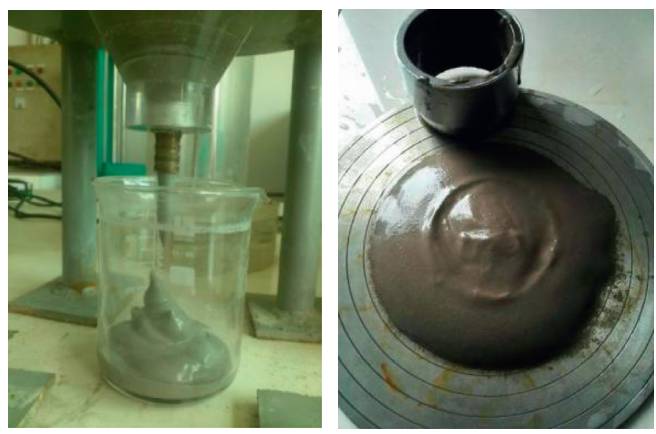

FIgURE 6: Underflow of dynamic thickening test.

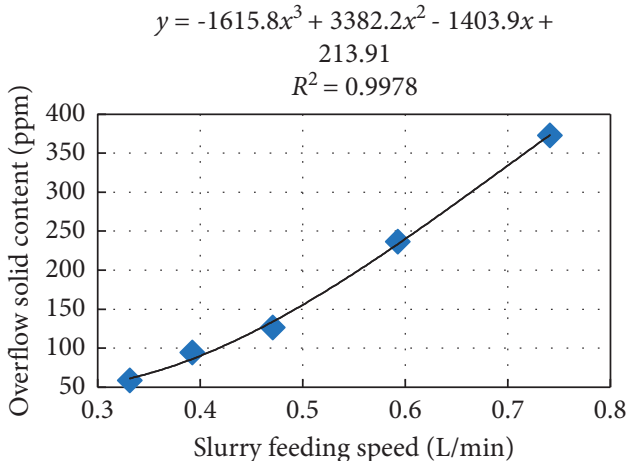

(a)

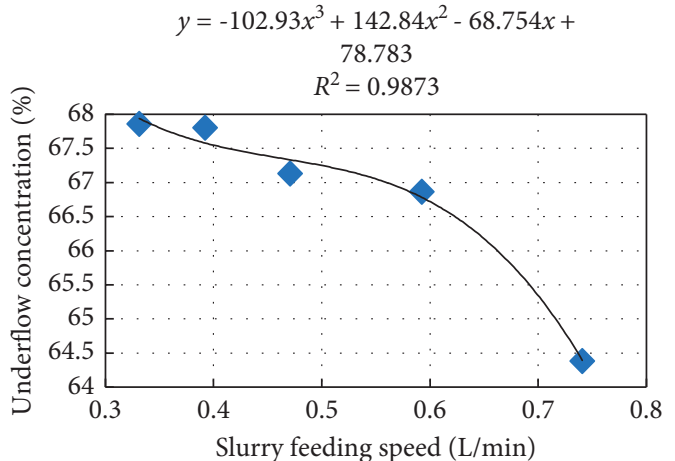

(b)

FIgURE 7: The relation between slurry feeding speed and (a) overflow solid content and (b) underflow concentration in mine 2.

TABLE 3: The correspondence table between overflow solid content and underflow concentration of dynamic thickening test.

\begin{tabular}{|c|c|c|c|c|c|c|c|c|c|}
\hline \multirow{2}{*}{$\begin{array}{l}\text { Sample } \\
\text { no. }\end{array}$} & \multirow{2}{*}{$\begin{array}{l}\text { Underflow } \\
\text { concentration } \\
\text { of static } \\
\text { settlement test } \\
C_{1}(\%)\end{array}$} & \multicolumn{2}{|c|}{$\begin{array}{l}\text { Overflow solid content } \\
\qquad 200 \mathrm{ppm}\end{array}$} & \multicolumn{2}{|c|}{$\begin{array}{l}\text { Overflow solid content } \\
\qquad 240 \mathrm{ppm}\end{array}$} & \multicolumn{2}{|c|}{$\begin{array}{l}\text { Overflow solid content } \\
\qquad 270 \mathrm{ppm}\end{array}$} & \multicolumn{2}{|c|}{$\begin{array}{l}\text { Overflow solid content } \\
\qquad 300 \mathrm{ppm}\end{array}$} \\
\hline & & $\begin{array}{c}\text { Feeding } \\
\text { speed } \\
v /(\mathrm{L} / \mathrm{min}) \\
\end{array}$ & $\begin{array}{c}\text { Underflow } \\
\text { concentration } \\
\mathrm{C}_{2}(\%)\end{array}$ & $\begin{array}{l}\text { Feeding } \\
\text { speed } \\
v /(\mathrm{L} / \mathrm{min}) \\
\end{array}$ & $\begin{array}{c}\text { Underflow } \\
\text { concentration } \\
C_{2}(\%) \\
\end{array}$ & $\begin{array}{c}\text { Feeding } \\
\text { speed } \\
v /(\mathrm{L} / \mathrm{min}) \\
\end{array}$ & $\begin{array}{c}\text { Underflow } \\
\text { concentration } \\
C_{2}(\%) \\
\end{array}$ & $\begin{array}{c}\text { Feeding } \\
\text { speed } \\
v /(\mathrm{L} / \mathrm{min}) \\
\end{array}$ & $\begin{array}{c}\text { Underflow } \\
\text { concentration } \\
C_{2}(\%)\end{array}$ \\
\hline Mine 1 & 53.1 & 0.256 & 66.71 & 0.269 & 66.57 & 0.277 & 66.50 & 0.284 & 66.45 \\
\hline Mine 2 & 53.5 & 0.554 & 67.03 & 0.600 & 66.72 & 0.632 & 66.40 & 0.664 & 65.98 \\
\hline Mine 3 & 42.7 & 0.704 & 52.65 & 0.749 & 52.47 & 0.778 & 52.38 & 0.804 & 52.31 \\
\hline Mine 4 & 59.5 & 0.608 & 72.21 & 0.630 & 71.98 & 0.645 & 71.80 & 0.658 & 71.61 \\
\hline Mine 5 & 55.3 & 0.739 & 68.56 & 0.789 & 67.49 & 0.825 & 66.99 & 0.861 & 66.84 \\
\hline Mine 6 & 59.3 & 0.640 & 71.73 & 0.670 & 71.45 & 0.689 & 71.25 & 0.705 & 71.06 \\
\hline Mine 7 & 68 & 0.624 & 79.25 & 0.665 & 78.86 & 0.691 & 78.61 & 0.714 & 78.39 \\
\hline Mine 8 & 64.7 & 0.694 & 77.29 & 0.754 & 77.06 & 0.799 & 76.90 & 0.846 & 76.73 \\
\hline Mine 9 & 63.8 & 0.668 & 76.946 & 0.706 & 75.99 & 0.733 & 75.16 & 0.760 & 74.22 \\
\hline
\end{tabular}

TABLE 4: The relation between slurry feeding speed and overflow solid content, and the relation between slurry feeding speed and underflow concentration.

\begin{tabular}{lcc}
\hline $\begin{array}{l}\text { Serial } \\
\text { no. }\end{array}$ & $\begin{array}{c}\text { Relation between slurry feeding speed } \mathrm{v} \text { and overflow } \\
\text { solid content } \mathrm{f}\end{array}$ & $\begin{array}{c}\text { Relation between slurry feeding speed } \mathrm{v} \text { and underflow concentration } \mathrm{C}_{2} \\
\text { of dynamic thickening test }\end{array}$ \\
\hline Mine 1 & $\mathrm{f}=95320 \mathrm{v}^{3}-48202 \mathrm{v}^{2}+8649.6 \mathrm{v}-454.18$ & $\mathrm{C}_{2}=508.71 \mathrm{v}^{3}-333.4 \mathrm{v}^{2}+59.851 \mathrm{v}+64.697$ \\
Mine 2 & $\mathrm{f}=-1615.8 \mathrm{v}^{3}+3382.8 \mathrm{v}^{2}-1403.9 \mathrm{v}+213.91$ & $\mathrm{C}_{2}=-102.93 \mathrm{v}^{3}+142.84 \mathrm{v}^{2}-68.754 \mathrm{v}+78.783$ \\
Mine 3 & $\mathrm{f}=1447.3 \mathrm{v}^{3}-1159.8 \mathrm{v}^{2}+280.3 \mathrm{v}+72.424$ & $\mathrm{C}_{2}=16.366 \mathrm{v}^{3}-26.464 \mathrm{v}^{2}+8.5418 \mathrm{v}+54.045$ \\
Mine 4 & $\mathrm{f}=8412.2 \mathrm{v}^{3}-8641.1 \mathrm{v}^{2}+2817.2 \mathrm{v}-208.62$ & $\mathrm{C}_{2}=-181.61 \mathrm{v}^{3}+272.61 \mathrm{v}^{2}-138.71 \mathrm{v}+96.583$ \\
Mine 5 & $\mathrm{f}=-1530.4 \mathrm{v}^{3}+3863.3 \mathrm{v}^{2}-2414.5 \mathrm{v}+491.75$ & $\mathrm{C}_{2}=337.78 \mathrm{v}^{3}-703.06 \mathrm{v}^{2}+460.95 \mathrm{v}-24.439$ \\
Mine 6 & $\mathrm{f}=8259.3 \mathrm{v}^{3}-11614 \mathrm{v}^{2}+5922.8 \mathrm{v}-998.1$ & $\mathrm{C}_{2}=-14.851 \mathrm{v}^{3}+3.464 \mathrm{v}^{2}+5.4232 \mathrm{v}+70.726$ \\
Mine 7 & $\mathrm{f}=3376.5 \mathrm{v}^{3}-3694 \mathrm{v}^{2}+1516.2 \mathrm{v}-127.88$ & $\mathrm{C}_{2}=8.9334 \mathrm{v}^{3}-22.005 \mathrm{v}^{2}+7.8756 \mathrm{v}+80.731$ \\
Mine 8 & $\mathrm{f}=-1478.3 \mathrm{v}^{3}+3283.9 \mathrm{v}^{2}-1763.8 \mathrm{v}+336.7$ & $\mathrm{C}_{2}=3.5566 \mathrm{v}^{3}-6.7487 \mathrm{v}^{2}+0.3892 \mathrm{v}+79.081$ \\
Mine 9 & $\mathrm{f}=-4884.2 \mathrm{v}^{3}+11018 \mathrm{v}^{2}-7171 \mathrm{v}+1529.9$ & $\mathrm{C}_{2}=-49.505 \mathrm{v}^{3}+24.464 \mathrm{v}^{2}+11.36 \mathrm{v}+73.191$
\end{tabular}




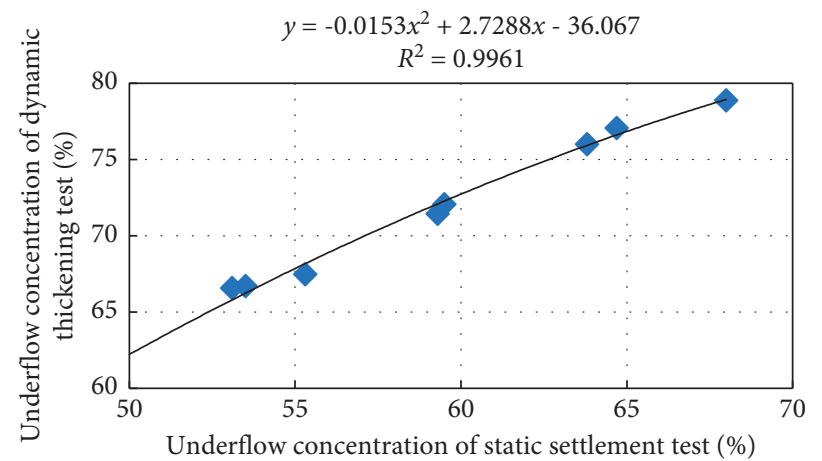

Figure 8: The relation between underflow concentration of static settlement test and underflow concentration of dynamic thickening test when overflow solid content is at $240 \mathrm{ppm}$.

TABLE 5: The relation between particle size and underflow concentration.

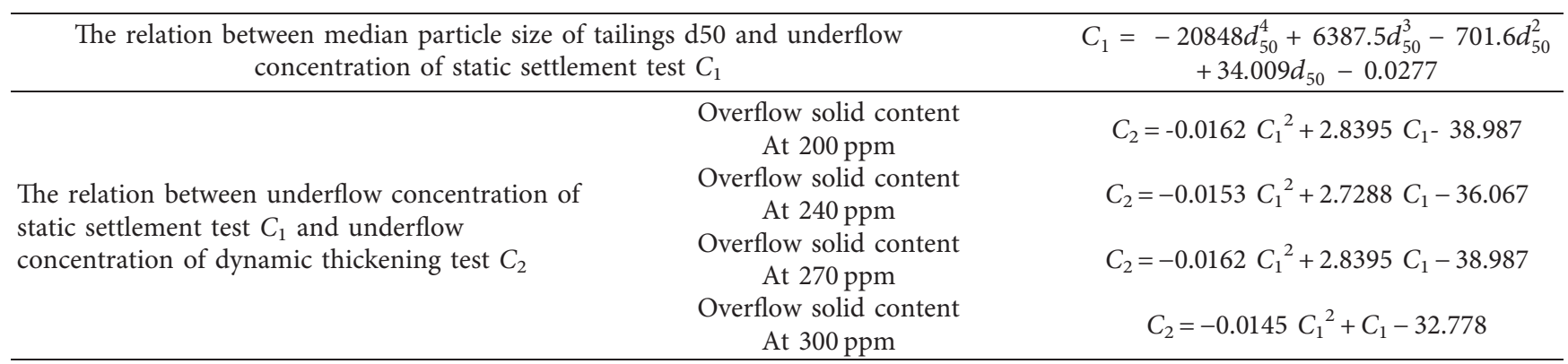

5.3. The Relation between Overflow Solid Content and Underflow Concentration of Dynamic Thickening Test. When the solid content of the overflow is $200 \mathrm{ppm}, 240 \mathrm{ppm}$, $270 \mathrm{ppm}$, and $300 \mathrm{ppm}$, the underflow concentrations of tailings in the 9 mines after treatment by the dynamic thickening device are shown in Table 4. It can be seen from Table 4 that the underflow concentration of the dynamic thickening test is $10 \% \sim 15 \%$ higher than that of the static settlement test. It means that the underflow concentration of the tailing slurry treated through dynamic thickening test by deep cone thickener is higher than that treated through static settlement test by tailing silo. This shows that the deep cone thickener can more effectively increase the underflow concentration, enhance the strength of the underground filling body, and increase the reliability of high-concentration slurry transportation.

5.4. The Relation between Underflow Concentration of Static Settlement Test and Underflow Concentration of Dynamic Thickening Test. When the solid content in the overflow water is $240 \mathrm{ppm}$, the relation between the underflow concentration of the static flocculation settlement test and the underflow concentration of the dynamic thickening test is shown in Figure 8. In Figure 8, it is not only the fitting curve of the underflow concentration $\mathrm{C} 1$ of the static settlement test and the underflow concentration C2 of the dynamic thickening test that are given but also the 2nd-degree polynomial function with its R-squared is given.

When the solid content of the overflow water is $200 \mathrm{ppm}$, $250 \mathrm{ppm}, 270 \mathrm{ppm}$, and $300 \mathrm{ppm}$, the relation between the underflow concentration of static flocculation settlement test and the underflow concentration of dynamic thickening test, and the relation between the tailings particle size and the dynamic thickening test underflow concentration are shown in Table 5. It can be known from Table 4 that given certain particle size of the tailings and the underflow concentration of the static flocculation settlement test and the dynamic thickening test can be predicted.

\section{Comparative Analysis of Calculation Results and Test Results}

When the tailing density, median particle size, and control particle size are known, the underflow concentration of each mine from the static settlement test and the underflow concentration of each mine from the dynamic settlement test under different overflow solid content conditions can be calculated by the formula obtained in Table 5 . When the solid content of the overflow is $240 \mathrm{ppm}$, the test results of the static and dynamic settlement tests of 9 mines are compared and analyzed with the calculation results. The details are given in Table 6 . It can be found from Table 6 that the relative error percentage of the calculated value and the 
TABLE 6: Comparison of calculation results and test results.

\begin{tabular}{|c|c|c|c|c|c|c|c|c|c|}
\hline \multirow{2}{*}{$\begin{array}{l}\text { Sample } \\
\text { no. }\end{array}$} & \multirow{2}{*}{$\begin{array}{c}\text { Ture } \\
\text { density } \\
\mathrm{g} / \mathrm{cm}^{3}\end{array}$} & \multirow{2}{*}{$\begin{array}{l}\text { Median } \\
\text { particle size } \\
d_{50}\end{array}$} & \multirow{2}{*}{$\begin{array}{l}\text { Control } \\
\text { particle size } \\
d_{60}\end{array}$} & \multicolumn{3}{|c|}{$\begin{array}{l}\text { Underflow concentration of static } \\
\text { settlement test }\end{array}$} & \multicolumn{3}{|c|}{$\begin{array}{l}\text { Underflow concentration of dynamic } \\
\text { settlement test when the solid conten } \\
\text { of overflow is } 240 \mathrm{ppm}\end{array}$} \\
\hline & & & & $\begin{array}{c}\text { Tested } \\
\text { value }(\%)\end{array}$ & $\begin{array}{l}\text { Calculated } \\
\text { value }(\%)\end{array}$ & $\begin{array}{l}\text { Relative } \\
\text { error (\%) }\end{array}$ & $\begin{array}{l}\text { Tested } \\
\text { value }\end{array}$ & $\begin{array}{l}\text { Calculated } \\
\text { value }\end{array}$ & $\begin{array}{l}\text { Relative } \\
\text { error }(\%)\end{array}$ \\
\hline Mine 1 & 2.010 & 0.0282 & 0.0391 & 53.1 & 50.35 & 5.18 & 66.57 & 62.54 & 6.06 \\
\hline Mine 2 & 2.611 & 0.0335 & 0.0423 & 53.5 & 53.81 & 0.58 & 66.72 & 66.47 & 0.37 \\
\hline Mine 3 & 2.322 & 0.0217 & 0.0302 & 42.7 & 44.06 & 3.18 & 52.47 & 54.46 & 3.79 \\
\hline Mine 4 & 2.871 & 0.0492 & 0.0625 & 59.5 & 58.58 & 1.55 & 71.98 & 71.28 & 0.97 \\
\hline Mine 5 & 2.880 & 0.0443 & 0.0540 & 55.3 & 57.70 & 4.35 & 67.49 & 70.45 & 4.39 \\
\hline Mine 6 & 2.560 & 0.0548 & 0.0723 & 59.3 & 59.22 & 0.13 & 71.45 & 71.88 & 0.60 \\
\hline Mine 7 & 2.689 & 0.1088 & 0.1407 & 68.0 & 67.26 & 1.10 & 78.86 & 78.25 & 0.77 \\
\hline Mine 8 & 2.451 & 0.1012 & 0.1288 & 64.7 & 66.22 & 2.34 & 77.06 & 77.54 & 0.62 \\
\hline Mine 9 & 3.009 & 0.0847 & 0.1055 & 63.8 & 62.79 & 1.59 & 75.99 & 74.95 & 1.37 \\
\hline
\end{tabular}

tested value of the underflow in either static or dynamic settlement test does not exceed $6.1 \%$, which shows that the curve equation obtained by regression analysis is reliable and can be used to guide actual production.

\section{Conclusions}

(1) Through the static settlement test, the optimal tailing slurry diluted concentration, underflow concentration, optimal flocculant type, and optimal amount of flocculant were determined for 9 typical mines. Different types of mines are with different optimal slurry diluted concentrations, generally about $10 \%$ to $18 \%$; the underflow concentration of the static settlement test is generally about $50 \%$ to $65 \%$ (when the tailings are particularly fine in size, the underflow concentration is less than $43 \%$. While the tailing particle size is particularly coarse, the underflow concentration can reach $68 \%$ ). The underflow concentration of the dynamic thickening test is $10 \% \sim 15 \%$ higher than that of the static flocculation settlement test. The coarser the particle size of tailings, the higher the underflow concentration. The optimal flocculant types and flocculant unit consumption vary when applied to different types of tailings. Type 83376 is the most widely used flocculant. The unit consumption of flocculant is generally about $7.5 \%$ $30 \%$. In general, the finer the tailings, the larger the amount of flocculant.

(2) The study found that the underflow concentration and the change in tailing slurry concentration are closely related to the tailing particle size. Through the nondimensional theoretical regression analysis method, the mathematical equations between the factors are obtained: number 1 relation equation between the median particle size of tailings and underflow concentration of static flocculation settlement test, and number 2 relation equation between the controlled particle size of the tailings and the change amount on underflow concentration of the static settlement test.
(3) Through the dynamic thickening test, equations of these 9 mines are obtained: number 1 relation equation between the tailing slurry feeding speed and the solid content of the overflow, number 2 relation equation between the feeding speed and the underflow of the dynamic thickening test, number 3 relation equation between underflow concentration of static settlement test and underflow concentration of dynamic thickening test with different overflow solid content, and number 4 relation equation between the tailing particle size and the tailing slurry underflow concentration with different overflow solid content.

(4) Comparing the calculation results with the test results of these 9 mines, it is found that the relative error between the predicted value and the test value does not exceed $6.1 \%$, which has proved that the relation equations derived are convenient and feasible. The underflow concentration of the deep cone thickener can be predicted by merely measuring the particle size of the tailings, which means that the relation equations are highly recommended for wider use and application.

\section{Data Availability}

The data used to support the findings of this study are available from the corresponding author upon request.

\section{Conflicts of Interest}

The authors declare that they have no conflicts of interest.

\section{Acknowledgments}

This study was financially supported by the 12th Five Years Key Programs for Science and Technology Development of China (2015BAB14B01) and the Postdoctoral Research Funding Plan in Hubei Province and Daye Nonferrous Metals Group Holdings Co., Ltd., for DM. 


\section{References}

[1] Q. Chen, Q. Zhang, and C. Qi, "Recycling phosphogypsum and construction demolition waste for cemented paste backfill and its environmental impact," Journal of Cleaner Production, vol. 186, pp. 418-429, 2018.

[2] L. Yang, H. Wang, and A. Wu, "Status and development tendency of the full-tailings paste mixing technology," Metal Mine, vol. 7, pp. 34-41, 2016.

[3] X. M. Gong, Z. J Y, and L. W. Guo, "Theory and technology of backfilling in deep mines," in Proceedings of the 2011 2nd International Conference on Mechanic Automation and Control Engineering, Inner Mongolia, China, July 2011.

[4] Q. Chen, Y. Tao, Y. Feng, Q. Zhang, and Y. Liu, "Utilization of modified copper slag activated by $\mathrm{Na} 2 \mathrm{SO} 4$ and $\mathrm{CaO}$ for unclassified lead/zinc mine tailings based cemented paste backfill," Journal of Environmental Management, vol. 290, p. 112608, 2021.

[5] Q. Zhang, Y. Li, Q. Chen, Y. K. Liu, Y. Feng, and D. L. Wang, "Effects of temperatures and $\mathrm{pH}$ values on rheological properties of cemented paste backfill," Journal of Central South University, vol. 28, no. 6, pp. 1707-1723, 2021.

[6] C. Qi, X. Tang, X. Dong, Q. Chen, A. Fourie, and E. Liu, "Towards Intelligent Mining for Backfill: a genetic programming-based method for strength forecasting of cemented paste backfill," Minerals Engineering, vol. 133, pp. 69-79, 2019.

[7] X. M. Wang, B. Zhao, and Q. L. Zhang, "Cemented backfilling technology with unclassified tailings based on vertical sand silo," Journal of Central South University of Technology, vol. 15, no. 6, pp. 801-807, 2008, (English Edition).

[8] X. Chen, X. Jin, H. Jiao, Y. Yang, and J. Liu, "Pore connectivity and dewatering mechanism of tailings bed in raking deepcone thickener process," Minerals, vol. 10, no. 4, p. 375, 2020.

[9] Q. Chen, Y. Tao, Q. Zhang, and C. Qi, "The rheological, mechanical and heavy metal leaching properties of cemented paste backfill under the influence of anionic polyacrylamide," Chemosphere, vol. 286, p. 131630, 2022.

[10] M. Sheshpari, "A review of underground mine backfilling methods with emphasis on cemented paste backfill," Electronic Journal of Geotechnical Engineering, vol. 20, no. 13, pp. 5183-5208, 2015.

[11] Q. Chen, S. Sun, Y. Liu, C. C. Qi, H. B. Zhou, and Q. L. Zhang, "Immobilization and leaching characteristics of fluoride from phosphogypsum-based cemented paste backfill," International Journal of Minerals, Metallurgy and Materials, vol. 28, no. 9, pp. 1440-1452, 2021.

[12] S. Wang, X. Song, X. J. Wang, Q. S. Chen, J. C. Qin, and Y. X. Ke, "Influence of coarse tailings on flocculation settlement," International Journal of Minerals Metallurgy and Materials, vol. 27, no. 8, pp. 1065-1074, 2020.

[13] X. Du, G. Feng, T. Qi, Y. Guo, Y. Zhang, and Z. Wang, "Failure characteristics of large unconfined cemented gangue backfill structure in partial backfill mining," Construction and Building Materials, vol. 194, pp. 257-265, 2019.

[14] C. Piao, D. Wang, H. Kang, H. He, C. Zhao, and W. Liu, "Model test study on overburden settlement law in coal seam backfill mining based on fiber Bragg grating technology," Arabian Journal of Geosciences, vol. 12, no. 13, pp. 1-9, 2019.

[15] J. Zhu, F. Liu, and Y. Xiong, "Experimental study on settlement characteristics of tailings with different particle size grading," Mining Research and Development, vol. 40, no. 5, pp. 41-44, 2020.
[16] C. Grangeia, P. Ávila, and M. Matias, "Mine tailings integrated investigations: the case of Rio tailings (Panasqueira Mine, Central Portugal)," Engineering Geology, vol. 123, no. 4, pp. 359-372, 2011.

[17] Arjmand R, Massinaei M, and A. Behnamfard, "Improving flocculation and dewatering performance of iron tailings thickeners," Journal of Water Process Engineering, vol. 31, pp. 1-8, 2019.

[18] J. Chen, Y. Chen, M. A. L. long et al., "Experimental analysis on tailings sedimentation regularity based on Altman method," Industrial Minerals \& Processing, vol. 48, no. 7, pp. 30-32 43, 2019.

[19] P. Dong, Research on Cementitious Materials and Rheological Properties of the Whole Tailings in Angang Iron, University of Science and Technology, Beijing, 2017.

[20] X.-min Wang, J.-wen Zhao, and De-ming Zhang, "Optimal prediction model of flocculating sedimentation velocity of unclassified tailings," Chinese Journal of Nonferrous Metals, vol. 03, pp. 793-798, 2015.

[21] Z. H. U. Li-yi, L. ü Wen-sheng, Y. Peng, and Z. Wang, "Influence of acoustic wave on thickening sedimentation of unclassified tailings," Chinese Journal of Nonferrous Metals, vol. 523, no. 1, pp. 2850-2859, 2020.

[22] Z. Gao, A. Wu, and H. Jiao, "Dynamic thickening sedimentation of unclassified tailings," Nonferrous Metals, vol. 69, no. 2, pp. 1-6, 2017.

[23] W. Gao, H. Wang, and C. Hui, "Study on main factors of underflow concentration in the dynamics thickening process of tailings," Metal Mine, vol. 485, no. 11, pp. 102-105, 2016.

[24] Z. Li, L. Guo, and X. Wei, "Research on flocculation and settlement mechanism of tailings slurry disturbed," Gold Science and Technology, vol. 27, no. 2, pp. 265-270, 2019.

[25] L. I. Gongcheng, Study on Size Change of Unclassified Tailings Floes and its Thickening Performance, University of Science and Technology, Beijing, 2018. 